\title{
Security Council Resolution 1325: Practice and Prospects
}

\author{
Reem Bahdi
}

\begin{abstract}
U nited N ations Security Council Resolution 1325 calls for a moreactive role for women in the prevention and reconciliation of conflicts. Focusing on the Palestinian Right of Return and the work of a feminist organization called the Jerusalem Link, this paper examines Resolution 1325's premise that women can make a unique contribution to peace building. As "transfer" or the ethnic cleansing of $\mathrm{Pa}$ lestinians from the West Bank and Gaza looms on the horizon, scholars, advocates, and policy-makers must pay more attention to the work of women peace-builders because they might be able to help chart a path towards a real and just solution on seemingly intractable issues such as the Right of Return.
\end{abstract}

\section{Résumé}

La résolution 1325 du Conseil de sécurité des $\mathrm{N}$ ations U nies recommande un rôle plus actif pour les femmes dans la prévention des conflits et la recherche de la paix et de la sécurité. Cet article se penche sur la question du Droit au retour des Palestiniens ainsi que sur le travail accompli par une organisation féministe du nom de Jerusalem Link, et étudie la prémisse de la résolution 1325 , qui présume que les femmes sont capables d'apporter une contribution unique au maintien dela paix. Alors que pointe à I'horizon le « transfert » ou, purification ethnique des Palestiniens de Cisjordanie et de la bande de Gaza, chercheurs, défenseurs et responsables politiques se doivent de porter plus d'attention au travail desfemmes pour la consolidation dela paix, car elles pourraient très bien pouvoir contribuer à l'élaboration d'une voiemenant vers une solution réelleet juste aux questions d'apparence insoluble, comme par exemplecelledu Droit au retour.
O n October 21, 2000, the United Nations Security Council adopted Resolution 1325 to promote a more active role for women in the prevention and reconciliation of conflicts. Resolution 1325 calls for "equal participation and full involvement of women in all efforts for the maintenance and promotion of peace and security, and the need to increase their role in decision-making with regard to conflict prevention and resolution." ${ }^{1}$ This paper examines Resolution 1325's premise that women can make a unique contribution to peace building while focusing on one of the most contested aspects of the I sraeli-Palestinian conflict, the Palestinian Right of Return.

N ot surprisingly, the Palestinian Right of Return represents a hard case for Security Council 1325. Debates over the Right of Return have generated controversy and anger on both sides of the conflict. Palestinians contend that refusal to recognize the Right of Return forms part of a consistent pattern of Israeli colonial ization and determination to deny Israel's responsibility for massive refugee suffering. ${ }^{2}$ Israelis tend to argue that Palestinian insistence on the Right of Return represents a cynical plot to destroy Israel through the back door. ${ }^{3}$ If women can help build the conditions necessary for peace and coexistence in the I sraeliPal estinian context, then they should be able to live up to the expectations of Security Council Resolution 1325 in other contexts.

This paper draws on interviews and discussionsheld with Israeli and Palestinian women in August 2002. ${ }^{4}$ Emphasis is placed on a joint Israeli-Pal estinian initiative called Jerusalem Link. Jerusal em Link's work with respect to the Right of Return suggests that, despite the odds, women can make and have made a unique contribution to shaping coexistence with and understanding of the "other." Jerusalem Link's efforts not only point to the possibility of an alternative framework for approaching the Palestinian Right of Return, but also suggest the efficacy of Security Council Resolution 1325. 
Part I of this paper provides a brief overview of Jerusalem Link's work on the Palestinian Right of Return. Part II delineates the reasons why the women of Jerusalem Link believe that they have succeeded in continuing dialogue on the Right of Return despite the failure of the region's politicians. Part III extrapolates from the work of Jerusalem Link to draw conclusions about the nature of Security Council Resolution 1325. U Itimately, with the Pal estinians sitting on the precipice of yet another refugee crisis under the current Israeli administration, scholars, policy analysts, or citizens concerned with the Middle East can no longer afford to ignore the work of Jerusalem Link or the Security Council's call for women's equal participation in promoting peace and security.

\section{Jerusalem Link's Unique Contribution Regarding the Right of Return}

Following a series of meetings first convened in Brussels in 1989, Jerusalem Link was formed in 1994 as a coordinating body of two independent women's centres: Bat Shalom, which islocated in I srael, and the erusalem Center for W omen, which is located in Palestine. Although each organization is autonomous and focuses on its own national constituency, the two organizations run joint programs promoting peace, democracy, human rights, and women'sleadership. On August 2, 1996, the two organizations issued the "Jerusalem Link Declaration of Principles." The Declaration sets out the organizations' joint commitment to certain principles, including recognition of the right of self-determination for both Israelis and Palestinians, the sharing of Jerusalem as two capitals for two states, recognition of the illegality of Israeli settlements, respect for international law, and theinvolvement of women in the development of ajust and viablepeace between the Israeli and Palestinian people. ${ }^{5}$ In its original formulation, the "Jerusalem Link Declaration of Principles" madeno mention of the Palestinian Right of Return. ${ }^{6}$

Inevitably, however, the two organizations embarked on the long, painful, and often frustrating path of discussing the Right of Return. Levels of trust between the Jerusalem Center for Women and Bat Shalom reached an all-timelow in 2001 and early $2002 .{ }^{7}$ Although the organizations maintained some level of communication, they came close to ending their long-standing relationship. Despite their best efforts, the women of J erusalem Link were not able to come to full agreement on the Right of Return. Instead, they articulated their differing positions in the "Jerusalem Link Declaration of Principles." The Declaration states the following with respect to the Right of Return:

Palestinian: Israel accepts its moral, legal, political and economic responsibility for the plight of Palestinian refugees and thus must accept the Right of Return according to relevant UN resolutions.

Israeli: I srael's recognition of its responsibility in the creation of thePalestinian refugees in 1948 is pre-requisite to finding a just and lasting resolution of the refugee problem in accordance with relevant $\mathrm{UN}$ resolutions. ${ }^{8}$

While the Palestinian position clearly sets out the Right of Return as an aspect of corrective justice, the Israeli formulation stops short of accepting I srael's "moral, legal, political and economic responsibility" for the creation of the Palestinian refugee problem in 1948. The Israeli position, however, does acknowledge that Israel had a role to play in driving out the refugees. M oreover, whilethe I sraeli version acknowledges the need for a just and lasting resolution, it does not explicitly recognize the Right of Return as an appropriateremedy, let al onetheap propriate remedy.

Although the Right of Return has challenged the relationship between Israeli and Palestinian women's organizations, there are fundamental features of J erusalem Link's discussions that distinguish their stance from those adopted by their societies at large. Perhaps most obviously, the "Jerusalem Link Declaration of Principles" moves beyond the simplistic and politically convenient claim that all Palestinians want to "drive Jews into the sea" ${ }^{9}$ and seeks, instead, to see Palestinians as human beings with claims to equal rights and dignity. To this end, the Declaration acknowl edges thewrongs doneto Pal estinian refugeesin 1948 and further recognizes that the state of I srael bears some level of responsibility for those wrongs. In the same vein, the Palestinian formulation, while insisting on the Right of Return for Palestinian refugees, simultaneously reaffirms the rights of both peoples to self-determination and peaceful coexistence. For example, article 1 of Jerusalem Link Declaration of Principles recognizes "the right to selfdetermination of both peoples in the land, to the establishment of a Pal estinian state al ongside Israel on the June 4, 1967 boundaries."

Seemingly, against all odds, members of Jerusal em Link have remained committed to continuing the dialogue and changing the current orientation towards violencethat pervades the political and popular discourse within their respective societies. The commitment to reaching a just solution through words rather than weapons can be attributed in part to the sheer determination of the individual women involved in the process. The women of Jerusalem Link also insist, however, that their dialogue must be structured in gendered ways that both reflect and reinforce the manner in which women tend to interact with each other. As Terry Greenblatt of Bat Shal om put it: 
[w]omen's characteristic life experience gives us the potentia for two things: a very special kind of intelligence, social intelligence, and a very special kind of courage, social courage. We have developed the courage to cross the lines of difference drawn between us, which are also the lines drawn inside our heads. And the intelligence to do it safely, without a gun or a bomb, and to do it productively. And most importantly, we are learning to shift our positions, finding ourselves moving towards each other, without tearing out our roots in the process. Even when we are women whose very existence and narrative contradicts each other, we will talk - we will not shoot. $^{10}$

Although they recognize that they have not al ways been true to these ideals in the past, the women of Jerusalem Link indicatea willingness to examineand re-examinethemselves at the same time that they question their partners in dialogue. In particular, the women prove willing to examine themselves rather than simply or exclusively blaming others for breakdowns in both trust and communication. ${ }^{11}$

In addition to their willingness to engage in introspection, the women of Jerusalem Link have recognized that a power imbalance characterizes the relationship between Bat Shalom and the Jerusalem Center for Women. They have sought to identify how such an imbalance might interfere with their own negotiations and interactions. ${ }^{12} \mathrm{Ac}$ cordingly, they do not seek to "negotiate" in the traditional adversarial, zero-sum model that stresses "what I win from you is my gain." Again, the path to this realization has not al ways been easy. Although they have not fully addressed the power imbalance that exists between them, the women of Jerusalem Link areincreasingly aware of theway in which the power imbalance may inhibit the devel opment of longterm, meaningful solutions. ${ }^{13}$ They understand the need to develop lasting agreements based on recognized principles that strive to have due regard for the common humanity of both peoples. ${ }^{14}$ Perhaps M aha Abu-Dayyeh Shamas expressed these points best when she reminded representatives of the U nited N ations Security Council that:

[t]he two parties, Palestinian and Israeli are not equal, and should not be left on their own, otherwise the imbalance of power will dictate the process, which characterized the Oslo negotiation process that we are now witnessing the bloody consequences of.

$\mathrm{H}$ onourable representatives, peace is made between peoples and not between leaders. A process that should lead to a political solution that is sustainable and consequently permanent should bejust, and should not be left to the confines of generals... 15
When seen in light of their willingness to examinethemselves and the power imbalances that exist between them, the fact that Jerusalem Link includes two principles, one Israeli and the other Palestinian, represents an expression of strength, commitment, and perseverance rather than an admission of despair. The two formulations reflect an understanding of the importance of accepting the other narrative as a starting point for authentic dialogue and meaningful negotiation. As Sumaya Farhat $N$ asser explained:

[w] omen understand the importance of narrativeand that they may begin with two different narratives. They have learned to listen with compassion and understand that others have the right to make mistakes. They have learned to bear (but not accept) painful words. Women do not force dialogue. ${ }^{16}$

Women's ability to continue discussions around the Right of Return is neither a chimera nor isit an inexplicable phenomenon. ${ }^{17} \mathrm{O} n$ the contrary, it has both theoretical and practical roots that are inextricably linked and sometimes difficult to disentangle, but that are nonetheless knowable and worthy of analysis. Anyone interested in finding a just solution for Palestinian refugees must ask how women can remain committed to continuing dialoguein theface of rising violence and intransigence around the Right of Return. The women of Jerusalem Link begin their discussions around the Right of Return with a few key, shared assumptions.

\section{Shared Assumptions}

A. Human Rights Framework

First, the women of Jerusalem Link adopt human rights and justice as their prevailing metaphors. ${ }^{18}$ Their discussions, therefore, take place within a framework that recognizes justice as a prerequisite to any lasting peace and that further requires individuals and states to take responsibility for their actions. In this regard, women see the importance of giving effect to human rights claims even though they may not necessarily or immediately agree on the substantive content of those claims. Accordingly, "Jerusalem Link Declaration of Principles" recognizes that:

[t]he realization of political peace will pave the way for mutual understanding, trust, genuinesecurity, and constructivecooperation on the basis of equality and respect for the national and human rights of both people. ${ }^{19}$

Women understand that human rights represent those things that recognize, respond to, and protect dignity and equality, and that these qualities are dialogical in nature. Any attempt to suppress the rights of others ultimately amounts to a personal tragedy ${ }^{20}$ and a devaluation of hu- 
man rights generally. ${ }^{21}$ Thus, although thewomen's groups may not have developed a shared set of principlesin relation to the Right of Return, they nonetheless remain committed to continuing their efforts in light of the simple fact that they are committed to negotiating towards justice, not injustices.

Significantly, the women of Jerusalem Link refuse to isolate the question of Palestinian refugees from the larger context of human rights issues that have plagued the I sraeIi-Pal estinian conflict. Bat Shal om expressed this point in a public letter to thePalestinian peoplepublished in AI Q ud's, a major Palestinian newspaper, on June 4, 2002:

We call for the removal of I sraeli settlements, for Jerusalem to serve as two capitals for two states, and for the acknowledgement by Israel of its part in creating the refugee problem and a mutually agreed upon resolution of the problem grounded in relevant UN resolutions. We insist that our humanity and commitment to justice not only connect us, Israelis and Palestinians, but also impel us to jointly continue our struggle for a just peace. ${ }^{22}$

By contrast, the mainstream discourse around the Right of Return tends to trivialize the rights claims of Palestinian refugees. ${ }^{23}$ At least some Israelis invoke Palestinian refugees as objects of sympathy rather than bearers of rights. ${ }^{24}$ Others weave the Palestinian Right of Return into a more hardened political discourse that aims to dehumanize Palestinians and their quest for self-determination..$^{25}$ The possibility that the human rights of $P$ al estinian refugees might havebeen violated and that the refugees have valid human rights claims barely enters into either of these calculations if at all.

Bat Shalom's position on Pal estinian refugees stands in marked contrast to both the official and mainstream I sraeli discourse on the Right of Return because it acknowledges the plight of the Palestinian refugees while invoking concepts of "humanity and justice." For this reason, a letter by Bat Shalom to the Palestinian people was well-received by the Jerusalem Center for Women even though it may have fallen short of meeting the Center's full expectations on the Right of Return. Bat Shalom's letter ultimately reflected the organization's willingness to understand the refugee issue as a long-standing and real human rights tragedy rather than a "faux" issuethat Palestinian's representatives invented to circumvent the negotiations with Israel. ${ }^{26}$

\section{B. Gender and Security}

Jerusalem Link adopts a gendered, wholistic definition of security that informs initiatives across issues, including the difficult question of the Right of Return. The women of J erusalem Link implicitly reject the conventional theoretical assumptions about the meaning and nature of "security" that inform much of the popular and political debate in the region. Security, especially in I sraeli society, is traditionally understood as military security and freedom from foreign threats, both real and perceived. ${ }^{27}$ Indeed, to the extent that they recognize Pal estinian refugees were driven from their homeland, Israeli historians tend to justify the expulsion of Pal estinian refugees in the name of Israeli state security. ${ }^{28}$

Women who find themselves embroiled in wars and conflict across the gl obe have ad opted an increasingly skeptical stancetowards the military's ability to provide security in any meaningful sense. ${ }^{29}$ This is true for several reasons. In the first place, women understand that "security" means more than freedom from foreign attack. "Security" also encompasses such things freedom from domestic violence, the ability to feed one's children, and the right to adequate, affordable housing. Israeli women, for example, question whether the military will in fact generate greater security for Israeli society when, as thelsraeli military budget spiralsout of control, women are effectively told that there is no money in the budget for social services because the military has eaten it all. ${ }^{30}$ The emphasis on military security actually undercuts women's security in other important spheres.

Traditional understandings of security derive from Thomas H obbes's social contract theory. ${ }^{31} \mathrm{H}$ obbes argued that free, rational individuals prefer order to chaos and will trade in their freedom as a means of overcoming chaos and obtaining security. ${ }^{32}$ Women's peace-building often challenges the Hobbesian premise that security and human rights must be traded off against each other. Women work under the premise that "security" can be achieved through, as opposed to limited by, an emphasis on human rights. In contrast to the traditional Hobbesian model, leaders in the women's peace-building movement understand the efficacy of responses based on horizontal social bonds rather than vertical state powers. ${ }^{33}$ They recognize that security is not a purchasable commodity but a relationship that must be cultivated. ${ }^{34}$

For the women of Jerusalem Link, the recognition that security is not a commodity requires them to tackle seemingly intractable political and social issues, like the Right of Return, by first recognizing the logic and efficacy of building lasting relationships with theindividuals and communities that affect one's life. Increasingly, the women of both Israel and Pal estine recognize that their fates are intimately linked with the fates of Pal estinian refugees, most of whom live in squalid refugee camps sprawled across the Middle East. While the current Israeli leadership aims to build a security wall between the two peoples, the women of Jerusalem know that Israeli and Palestinian lives cannot be segregated in this way because in the end, security is built, 
not with bricks and mortar, but through negotiated agree ments that respect the dignity and worth of all parties involved. ${ }^{35}$ To this end, "Jerusalem Link Declaration of Principles" acknowledges that any agreement that dismisses the suffering of the Palestinian refugees is neither legitimate nor sustainable in the long term.

Jerusalem Link's normative shift around the meaning of security also challenges the premise that security analysis should remain specialized in the hands of the military and intelligence services that have a bias in favour of militarystyle solutions. ${ }^{36} \mathrm{~W}$ omen peace-builders around the gl obe ap preciate that military-style solutions may aggravate security threats rather than ameliorate them, and that such professed solutions limit the national capacity to consider creative responses to crises. ${ }^{37}$ For this reason, the women of Jerusal em Link worry that I srael's leaders are promoting a new "transfer" policy.

Perhaps one of the clearest and most disturbing indications of the growing political and popular divide between Israelis and Palestinians lies in the increasingly popularity of "expulsion" or "transfer" among I sraeli politicians and thegeneral populace. ${ }^{38}$ These terms represent the politically correct alternative to ethnic cleansing or the forced expulsion of Palestinians from the West Bank and Gaza. Even some Palestinian women who are committed to ongoing dialogue and who have dedicated their lives to finding common ground with Israel see "transfer" looming on the horizon. ${ }^{39}$ The women of Jerusalem Link know that "transfer" will not only signal the moral degeneration of the state of Israel, but will also create another generation of disenfranchised and despairing Palestinian youth, who will seek suicidal revenge against Israel is for the ongoing and escalating violence wrought upon Palestinians. ${ }^{40}$ Fearful of the rising spectre of "transfer" and escalating violence, both Israeli and Palestinian women have rallied around the slogan, "We have tried war al ready." 41

Globally, women's commitment to solutions beyond the military derives from their knowledge that they have been and will continue to be excluded from decision making when the military steps in. ${ }^{42}$ Some Israeli and Palestinian women, at least, havearrived at thesame realization. In Israel, a movement called "Women Refuse!" aims for the demilitarization of Israeli society and calls for women to stop cooperating with thel sraeli military government and itspolicies:

Women Refusecallsupon all women to stop being traditionally silent and to dare to raise their voices by opposing their loved ones' participation in military action. This new form of protest opposes a deeply rooted national tradition of unquestioned support for the Israeli military... It calls on the Israeli public to refuse to bethe enemy and to develop a new national dialogue.
By starting within our homes and then moving out into wider public domains, Women Refuse is attempting to create a new national agenda.

Palestinian women find their political participation has diminished in the wake of the second Intifada in part because this Intifada, as opposed to the first, regards armed struggle as the source of freedom. ${ }^{44}$ While Palestinian women remain divided on the efficacy of adopting a militarystyle form of resistance to Israeli occupation, they nonetheless tend to recognize this tendency excludes them from public or political participation. ${ }^{45}$

\section{Understanding Structural Violence}

Finally, women have proven themselves ableto continue the difficult dial ogue around the Right of Return because they conceptualize violence through their own vulnerability. They understand that the violence in their homes is intimately connected to violenceon thestreets. They know violence not only as the act of individuals but as a structured event that grows out of social institutions and organizational models. In other words, women know and have felt the hand of structural violence. O ccupation in all its manifestations has taken a heavy toll on women in both I sraeli and Palestinian societies. Although the necessary research has not been conducted to determine the full effects of occupation and militarization on women in both I srael and Palestine, it is clear that "women suffer most from the conflict." ${ }^{46}$ This paper can only provide a glimpse into the daily lives of Israeli and Palestinian women. ${ }^{47}$

In Israel, the Sharon government remains committed to an expensive military machine while the Israeli economy suffers its deepest recession in fifty years. ${ }^{48} \mathrm{~W}$ omen suffer disproportionately because they traditionally have not enjoyed equal status with men within Israeli society. For example, the United Nations Committee on the Elimination of Discrimination against W omen, in its last review of Israel, noted with concern that a marked disparity existed between the average earnings of women and men in many sectors, that a large number of women were arrested for prostitution, and that violence against women occurred frequently, owing in large measure to traditional ideas of the roles of women within Israeli society. The Committee al so noted with concern that non-Jewish women had worse living conditions than Jewish women. They received a lower level of education, participated less in the government service, and occupied limited decision-making posts. ${ }^{49}$

In Palestine, women and their babies die becausethey are not permitted by Israeli soldiers to pass through checkpoints so that they can receive necessary medical treatment at hospitals. ${ }^{50}$ W omen and girls are al so sexually assaulted 
by Israeli soldiers with impunity. ${ }^{51}$ Palestinian women see their children shot, wounded, and traumatized by the occupying Israeli army. ${ }^{52}$ In Gaza, the concept of honour, previously associated with land, is now increasingly tied to women's virginity within Palestinian society. ${ }^{53} \mathrm{As}$ a result, so called "honour crimes" have risen over the last decade. ${ }^{54}$ Indeed, domestic violence in general has al so risen dramatically in both Israeli and Palestinian society. ${ }^{55}$

In addition, women are further traumatized by the violations, indignity, and cruelty suffered by their family members as a result of occupation. These violations are rarely acknowledged outside of Pal estinian society. Asoneleading Israeli journalist put it, "cruelty against Palestinians has grown gradually and this means that it is accepted within Israeli society." ${ }^{56}$ For example, one woman recounted a chilling story about the siege of Jenin by the Israeli army. Israeli soldiers encircled a community centre and ordered all the men to leave the building with their hands in the air. They then ordered all the women and children to leave the building in a separate group. However, the Imam of the community remained behind with the women and children so that he could assist his disabled elderly mother exit the building; he therefore did not leave with the men when ordered out of the community centre by the soldiers. ${ }^{57}$ U pon seeing the M uslim cleric, a number of Israeli soldiers began to laugh and joked that he clearly did not know if he was a man or a woman. They ordered the cleric to strip naked and then forced him to carry his elderly mother out of the building into a waiting vehicle that was full of women. This intentional infliction of mental anguish and humiliation upon the cleric amounts to psychological torture ${ }^{58}$ and has produced untold anguish for the cleric and hisfamily. H is wife, who was forced to witness the incident, remains traumatized.

Feminist advocates around the world know that although they may appear unrelated, forms of structural violence may be intimately connected. ${ }^{59}$ In Israel and Palestine, the violence of occupation, the Intifada, and Israeli military repression mergewith theviolencevisited upon women in the so called "private" sphere and thrive upon each other. As $M$ ahaAbu-Dayyeh Shamasexplains, women, becausetheyare most vulnerable to violence, tend to see the spectrum of domination more readily and tend to appreciate that domination cannot produce lasting coexistence:

Policies based on mistrust and domination are not sustainable, and we women know this - we know it too well. Such policies are not sustainable in the private sphere, nor are they sustainable in the public sphere. ${ }^{60}$

Because women have experienced structural violence, women are more willing to see and question the structural violence committed against Palestinian refugees in the name of state security. They tend to be skeptical about the claim that it was necessary to drivetherefugees from their historic homes in the name of Israel's national security. ${ }^{61}$ They know that the violence that was visited upon the refugees decades ago continues to haunt the state of Israel, and continues to affect the lives of both Israeli and Palestinian women who live in the region in tragic yet ultimately predictable ways. In short, women understand that the violence favoured by politicians and military against the "other" rebounds onto their own societies and that women, as a result, are disproportionately disempowered and harmed. ${ }^{62}$ In theend, though the Palestinian refugees may have been driven out of their homesto foreign lands, theviolence that drove them out remains and continues to haunt those who live in both Israel and Palestine. Neither religion nor national ity acts as a complete shield to the violence born of past wrongs.

Disproportionately linked by their gender through their vulnerability to violence, the women of Jerusalem Link also understand that the bonds of gender can prove a source of creativity, energy, humanity, and hope. ${ }^{63}$ In this regard, Jerusalem Link represents a microcosm of a larger movement within Israel and Palestine, which seeks to construct gender in general and motherhood in particular as a bridge to help span divides, including those built on nationality and religion. ${ }^{64} \mathrm{As}$ women throughout the ages have turned to their motherhood status to help subvert the status quo, individual women in both Israel and Palestine recognize that they are connected by motherhood even though they may be divided by nationality, religion, or other elements of identity. ${ }^{65}$

This possibility of seeing and sympathizing with the "other" through the lens of motherhood is eloquently and passionately expressed in the wounded yet powerful words of a Palestinian mother who wrote:

I wept today and you will weep tomorrow

M aybe you've wept for your husband and

Tomorrow you'll weep for your son.

Let me tell you,

I've already wept for both my son and my husband

I wish I could walk into every house around carrying within me Anguish and heartache and mourning.

Come mother of I brahim and mother of I tzhak,

Let's weep together, you and me.

Longing for our loved ones unites us, you and me.

Motherhood unites us, you and me.

The heart aches. 
Let's remember if in life there is no place for us on this earth, We have place enough under it.

Let's pray together mother of Ibrahim and mother of I tzhak.

I and you are the conscience.

I and you are the love and bridge.

I and you are the bridge to truth. ${ }^{66}$

Thesesentiments of Palestinian motherhood find their echo in the words of an Israeli mother whose daughter was killed by a suicide bomber:

In the kingdom of death,

Israeli children lie beside Palestinian children,

soldiers of the occupying army beside the suicide bombers,

and no one remembers

who was David and who was Goliath. ${ }^{67}$

\section{Gender and Peace-Building: Challenges and Prospects}

Women's groups in Israel and Palestine face formidable obstacles. Women peace-builders represent voices in the wilderness in an increasingly polarized political and popular landscape. Both Bat Shalom and the Jerusalem Center for Women oscillate between maintaining legitimacy within their own societies and seeking to press the public discourse. ${ }^{68}$ They cannot stray too far from their respective public opinion or they risk alienating most of their supporters. Yet, as agents of change, they must seek to challenge popular perceptions and point to barely imaginablealternative ways of seeing and doing. As Terry Greenblatt of Bat Shal om put it, "women's groups dance between acceptance and challenging our own societies." 69

Some might dismiss "Jerusalem Link Declaration of Principles" as a trivial or meaningless document because it was not drafted in the halls of power. They might arguethat the dialogue nurtured between Bat Shal om and the Jerusalem Center for Women represents an easy accomplishment because not much rests on such dialogue. This objection, however, misses the mark in part because the relationship between Bat Shalom and the Jerusalem Center for women has proven to be anything but easy. The women of Jerusalem Link place themselves at personal, professional, and political risk by signing the Declaration and taking a public stance in support of the values articulated therein. ${ }^{70}$ They have been personally threatened and denounced as traitors in their own societies. ${ }^{71}$ Israeli women in particular saw many of their allies within themainstream peacemovement and political parties, including somewomen, takea dramatic turn to the political right with theoutbreak of theSecond Intifada. ${ }^{72}$ Women's peace groups have also seen funding from progressive Jewish organizations around the world dry up since September $11 .^{73}$ Palestinian women, for their part, face increasing political isolation in the face of rising violence associated with the Second Intifada. ${ }^{74}$

Moreover, as the Oslo process has demonstrated, the solutions of military and political leaders must have some resonance within civil society. Accordscannot lead to peace or coexistence on their own. One must al so be attentive to thereality "on theground." "75 Thewomen of Jerusalem Link clearly appreciate that peace building must take place at the level of civil society. They are not escapists or ideal ists. They are advocates who are intimately connected to and concerned about their societies. Terry Greenblatt of Bat Shalom emphasized, "We are struggling to maintain credibility in an increasingly divided political situation. The key question for us is "how do we as women provide direction out of here?"'76

Yet, the women of Jerusalem Link cultivate empowerment rather than power. ${ }^{77}$ This fact should emphasize their political legitimacy and underscore the viability of their efforts to develop an alternative political discourse. In the end, the official negotiations between Israelis and Palestinians failed in part because the leaders proved more concerned about securing power through elections than remaining adequately attentive to those voices muted by the political process. The women of J erusalem Link have demonstrated that it is possible to frame discussions around the Right of Return that recognize the narratives, hopes, and fears of both the Israeli and Palestinian people. While they have yet to reach full agreement, their efforts at developing an alternative discourse around the Right of Return reinforces that agreement between negotiators and political leaders may be necessary but not sufficient for political success.

Undoubtedly, there are lessons to be drawn from Jerusalem Link's Declaration and the difficult path of dialogue around the Right of Return. Jerusalem Link's activities also prove significant because they help shed light on the conditionsnecessary to promotewomen's contribution to peace building as contemplated under Security Council Resolution 1325. This resolution draws upon diverse and sometimes contradictory strands of feminist theory including cultural feminism, dominance theory, and liberal feminism. It has only just begun to attract significant attention from feminist scholars. Yet, the women of Jerusalem Link have been putting the principles of Resolution 1325 into practice for close to a decade.

Jerusalem Link's experiencesuggeststhat Security Council Resolution 1325 cannot imply a simple "add women and stir" approach to peace building. Simply seating more women at negotiating tables or within the ranks of the military will not necessarily lighten the path to coexistence and understanding. Women arealready included in the military 
and government decision-making processes, al beit in relatively small numbers. Yet, when they are included in the halls of power as currently constituted, women inevitably come to share in the masculine military culture. The need is to recast the military culture and recast the national military metaphors. ${ }^{78}$ Second, negotiations must start with an understanding of the present lived realities of the refugees and an agreement over the historical context that produced the refugee problem. This need to understand history does not amount to some nostalgic desire to turn back the hands of time, but acknowledges that true understanding cannot be had without understanding of context and narratives. ${ }^{79}$ Third, negotiations are not successful when "the winner takes all." Rather, they must aim to produce just and lasting solutions that are attentive to the stories that have been papered over and silenced by official accounts of history just as women's voices have been silenced. Finally, women are victims of war and occupation, yet they are not helpless. On the contrary, women are leaders in their communities. During times of war and conflict, they help preserve a degree of civility and their work can affirm the need for recognition of the "other's" common humanity. Resolution 1325 must not simply bring morewomen to thenegotiating table. It must instead bring thebrokers of power who sit at the negotiating table to understand the lived realities of Palestinian refugees, those whose individual and collective lives are torn asunder by conflict.

\section{Conclusion}

Jerusalem Link's success in charting a just agreement on the Right of Return is by no means guaranteed. Women have found themselves on the edge of the precipice on several occasions but nonetheless found their way back to former ground. They havelearned that onecannot address the Right of Return unless one adopts a broader framework based on the principles of justice and recognition of the common humanity of Palestinian refugees. As "transfer" loomson the Palestinian horizon, scholars, advocates, and policy-makers in I srael, Palestine, and beyond must pay moreattention to the work of women peace-builders because they might be able to help chart a path towards a real and just solution on seemingly intractable issues such as the Right of Return.

\section{Notes}

1. UN SC Res. 1325 (2000), adopted by the Security Council at its $4213^{\text {th }}$ meeting, 310 ctober 2000; available online: $<$ http://www.un.org/events/res_1325e.pdf > (date accessed: 28 February 2003).

2. See, for example, B. Abushagra, "The Palestinian Refugee Problem and the Right of Return," online: The Palestinian I nitiativefor thePromotion of Global Dialogueand Democra- cy Homepage <http://www.miftah.org/Display.cfm?D ocld=1198\& Categoryld=21 > (date accessed: 28 February 2003).

3. AsDanny Rubinstein explains, thePal estinian Right of Return "represents, to most Israelis, the destruction of I srael because it threatens the forcibly maintained Jewish majority, or, as it is often put the 'Jewish character' of the state." D. Rubinstein, "The Return of the Right of Return," online: $\mathrm{H}$ a'aretz H omepage <http://www.un.org/events/res_1325e.pdf> (dateaccessed: 28 February 2003).

4. These interviews were conducted by a cross-disciplinary team of Canadian women. Theteam included both J ewish and A rab women. M embers of the team were Leilani Farha, Rula Sharkawi, Audrey M acklin, Reem Bahdi, Judith W eisman, H anadi Lubani, Kemi Jacobs, I sabel Sel on-H elal, and Kathy Wazana. Theopinions and conclusion expressed in this paper arethose of the author and do not necessarily reflect the individual or collective opinions of the women who attended this mission.

5. The full text of the "J erusalem Link Declaration of Principles of Principles" [ hereinafter "Declaration"] can befound online: Bat Shalom of the Jerusalem Link Homepage <http://www. batshalom.org/2002/The\%20] erusalem $\% 20$ Link\%20D eclaration $\% 20$ of\%20Principles.htm > (date accessed: 28 February 2003).

6. TheAugust 1996 version of "The Jerusalem Link Declaration" can befound on-line: Bat Shalom of the erusalem Link H omepage <http://www.batshalom.org/JerLinkD ecl.htm> (dateaccessed: 28 February 2003).

7. Interview of Terry Greenblatt, Executive Director of Bat ShaIom (5 August 2002), Jerusalem [hereinafter "Interview, Greenblatt"]; Interview of Amneh Badran, Executive Director of the Jerusalem Center for Women, Jerusalem (5 August 2002), Jerusalem [hereinafter "Interview, Badran"].

8. Declaration, supra note 5.

9. Interview, Greenblatt, supra note 7: "We are attempting to produce an alternative discourse to challenge the prevailing Israeli perception that Palestinians are all maniacs who want to drive us to the sea."

10. Terry Greenblatt also made this point in a speech to members of the United Nations Security Council. Terry Greenblatt, "Terry Greenblatt, Director of Bat Shal om, Speaks Before U N Security Council," online: Coalition of Women for Peace H omepage <http://www.coalitionofwomen4peace.org/articles/ terrybeforesecuritycouncil.htm> (date accessed: 28 February 2003 [hereinafter "Greenblatt, Security Council"].

11. Interview, Badran, supra note 7; Interview, Greenblatt, supra note 7. See also the Jerusalem Center for Women, "Summary Annual Report 2001," online: The Jerusalem Center for W omen Homepage <http://www.j-c-w.org/annual_report_ 2001.htm> (date accessed: 28 February 2003).

12. Ibid.

13. Interview, Greenblatt, supra note 7.

14. Several women interviewed emphasized that I sraelis and Palestinians see each other through the lens of those in power; thereislittlepersonal interaction. Interview, Greenblatt, supra 
note 7; Interview of Amira Hass (9 August 2002), Jerusalem [hereinafter Interview, Hass]; Interview of Sumaya Farhat Nasser (11August 2002) , Bir Zeit, Pal estine[ hereinafter Interview, Nasser].

15. Maha Abu-Dayyeh Shamas, "Maha Abu-Dayyeh Shamas, ExecutiveDirector of the Jeruselum W omen'sCentrefor Legal Aid and Counselling, to the UN Security Council," online: Margie Adam - A Woman's M usic H omepage <http://www. margieadam.com/action/mashamas.htm > (date accessed: 28 February 2003) [hereinafter Shamas, Security Council]. M aha Abu-D ayyeh Shamas is also a board member of theJ erusalem Center for Women.

16. Interview, Nasser, supra note 14

17. Greenblatt, Security Council, supra note 10.

18. Article 7 of the Jerusalem Link Declaration of Principles reads: "Respect for international conventions, charters and laws and the active involvement of the international community in the peace process are crucial to its success." Declaration, supra note 5 .

19. Declaration, supra note 5 at Article 8.

20. Terry Greenblatt writes: "And perhaps the greatest fear of all, theonethat livesinsidemy J ewish closet and that I rarely share publicly is that because I might ultimately be unable to live with so much fear and contradiction - because I fear for my family's survival, my nation's survival - that one day, possibly tomorrow, I will read another short article in the newspaper about another woman, another birth, at another checkpoint, in another city. And I will rinse my coffee cup in the sink, set it to dry on thedrain - and no longer beoutraged and afraid." Theabovestatement isfrom thekeynotepresentation by Terry Greenblatt of Bat Shalom (preceded by M aha Abu-Dayyeh Shamas of the Jerusalem Center for Women, Women's Centre for Legal Aid and Counseling) at A Day of Dialogue: A World of Women for W orld Peace. Theday wasorganized by Congresswoman EddieBernice Johnson, and held at the Library of Congress on $M$ ay 9,2002 . The presentation is available online: $<$ <ttp://www.beyondblame.info/organizations/jerusalemlin k/gr eenblatt.html> (date accessed: 28 February 2003).

21. April 2002 Joint Declaration, available online: <http://www. batshalom.org/2002/DECLARATIONS\%20\&\%20POLITI CAL \%20STATEM ENTS> (dateaccessed: 28 February 2003).

22. Bat Shalom, "A Public Letter to the Palestinian People," online: Bat Shalom of the Jerusalem Link, <http://www.batshalom.org/2002/jerusale-link_current_activities.htm> (date accessed: 28 February 2003).

23. See, for example, M. Bard, "ThePalestinian Refugees," online: Bat Shalom of the Jerusalem Link, <http://www.us-israel. org/jsource/History/refugees.html> (date accessed: 28 February 2003). Bard describes the Palestinian people largely in military terms.

24. See, for example, the interviews conducted by E. Farnsworth, "Debating the Right of Return," online: PBS Homepage $<$ <ttp://www.pbs.org/newshour/bb/middle_east/july-dec00/ pale stinians_8-29.html> (date accessed: 28 February 2003).
25. See, for example, A. Afak, "What Right of Return?" online: I sraelForum.com H omepage <http://www.israelforum. com/board/showthread.php3?s=e6fe139 353059acfbd57d92 b9472ebc0\&postid = 39793\#post39793> (date accessed: 28 February 2003). Abu Afak quotes Alan Dershowitz.

26. A. Gresh, "TheM iddleEast: How the PeaceW as Lost," online: Le M onde Diplomatique Homepage <http://mondediplo. com/2001/09/01middleeastleader > (dateaccessed: 28 February 2003). Gresh observes that:

[f]or the overwhelming majority of Israelis, when Yasser Arafat rejected the 'generous offer' made at the [Camp David] summit, he 'exposed his true face', as Ehud Barak put it. And by supporting Arafat, the Palestinian people were confirming their barely-concealed intent to destroy Israel.

27. R. Hiller, "Chipping Away at the Core," online: New Profile Homepage <http://www.newprofile.org/english/> (date accessed: 28 February 2003). Hiller talks about her experience of working with groupsthat challengetwo of I srael i society's deep foundations: militarism and patriarchy. Seealso L. Raz, "From the Cradle to the Grave," online: New Profile Homepage $<$ <ttp://www.newprofile.org/english/> (date accessed: $28 \mathrm{Fe}$ bruary 2003). Raz explainshow ideals of heroism, strength and security, conspire to create an "inhumanly" militarized existence for I sraeli men.

28. See, for example, B. Morris, "A N ew Exodus for the Middle East," online: Guardian Unlimited <http://www.guardian. co.uk/israel/comment/0,10551,803417,00 .html > (date accessed: 28 February 2003).

29. B. M uthien, "Women's Security Is H uman Security: Southern Dimension," online: Copenhagen Peace Research Institute H omepage <http://www.copri.dk/ipra/Conf-papers/muthiengenderedsecur ity.doc> at 6 (date accessed: 15 J anuary 2003).

30. In M ay 2002, A riel Sharon introduced an austerity package of tax increases and welfare cuts designed to help pay for I srael's military operations against the Palestinians. See "Sharon Gets Crucial Budget Vote," online: BBC N ews H omepage <http:// news.bbc.co.uk/1/hi/world/middle_east/2001340.stm > (date accessed: 28 February 2003).

31. M. Valverde, "Governing Security, Governing through Security," in R. Daniels et al., eds., The Security of Freedom (Toronto: University of Toronto Press, 2001) at 83.

32. T. Hobbes, Leviathan (New York: Penguin Classics, 1968 (1651)). See especially Chapter 17, "Of The Causes, Generation, And Definition Of A Commonwealth," where Hobbes describes the Leviathan:

I authoriseand give up my right of governing myself to this man, or to this assembly of men, on this condition; that thou give up, thy right to him, and authorise all his actions in like manner. This done, the multitude so united in one person is called a COM M ON WEALTH; in Latin, CIVITAS. Thisis the generation of that great LEVIATH AN , or rather, to speak more reverently, of that mortal god to which we owe, under theimmortal God, our peace and defence. For by this authority, given him by every particular man in the 
Commonwealth, he hath the use of so much power and strength conferred on him that, by terror thereof, he is enabled to form the wills of them all, to peace at home, and mutual aid against their enemies abroad. And in him consisteth the essence of the Commonwealth; which, to define it, is: one person, of whose acts a great multitude, by mutual covenants one with another, have made themselves every one the author, to the end he may use the strength and means of them all as he shall think expedient for their peace and common defence.

33. Interview, Badran, supra note 7. "Women have different concerns than men. Rather than speaking of traditional conceptions of security or definitions of sovereignty, women's issues relate to family and social justice."

34. Valverde, supra note 31 at 84,87 .

35. See, for example, "Response from the Jerusalem Center for Women," online: Bat Shalom of the Jerusalem Link Homepage <http://www.batshalom.org/2002/jerusale-ink_current_activities.htm> (date accessed: 28 February 2003).

36. See Valverde, supra note 31 at 87 for a discussion of the relationship between "security professionals" and true security.

37. See generally S.N. Anderlini, Women At The Peace Table: M aking A Difference (N ew York: U NIFEM , 2000).

38. See, for example, M oledet's website, which proclaims: Moledet ("homeland" in Hebrew) is an ideological political party in I srael that embraces the idea of population transfer... M oledet has successfully raised the idea of transfer in the public discourse and political arena in both Israel and abroad, within the framework of achieving comprehensive peace in this region. Moledet is also actively involved in establishing these facts on the ground, by encouraging the emigration of displaced and hostile elements from our Land. Over the years, M oledet had worked to strengthen Jewish settlement in all parts of the land of Israel and to establish high quality of life for its residents, based on Jewish and democratic values and a true caring for the future of our State.

Available online: M oledet H omepage <http://www.moledet. org.il/english/moledet.html> (date accessed: 28 February 2003).

39. One Palestinian woman interviewed by the Canadian Women's M ission to Israel and Palestine, August 2002, said that she has al ready packed her family's suitcase. Others insist that thereisno valuein speaking about "transfer" becausespeaking about the issue simply gives it greater currency as a subject of legitimate "debate" in popular and political circles.

40. Interview, Greenblatt, supra note 7 .

41. This was the message on a sign at a Bat Shalom Sukkat (Peace Tent). See Sukkat H aShalom "Rocks Land Like M essages Sent in a Bottle," online: Women W aging PeaceH omepage <http:// www.womenwagingpeace.net/content/whatwedo/newsevent s/2hashalom. asp > (date accessed: 28 February 2003).

42. Interview of M iftah (10 August 2002), Ramallah, Palestine [hereinafter Interview, M iftah].
43. Hiller, supra note 27. Hiller talks about her experience of working with groupsthat challengetwo of I sraeli society's deep foundations: militarism and patriarchy. See also Raz, supra note 27. Raz explains how ideals of heroism, strength, and security conspire to create an "inhumanly" militarized existence for Israeli men.

44. Interview, M iftah, supra note 42.

45. Interview, M iftah, supra note 42.

46. Interview, Badran, supra note 7.

47. For a fuller account, see Report of the Canadian Women's M ission to Israel and Palestine, August 2002 (forthcoming).

48. E. Clark, "Israel's neglected economy," online: BBC News Homepage <http://www.news.bbc.co.uk/1/lowin depth/ world/2002/september_11_one_year_on/2207071.stm> (date accessed: 20 February 2003).

49. "Committee on the Elimination of Discrimination against Women, Concluding Observations: Israel, U.N. DoC. A/52/38/Rev.1, Part Il paras.132-183 (1997)," online: U niversity of M innesota H uman Rights Library H omepage <http:// www1.umn.edu/humanrts/cedaw/cedaw-israel.htm > (date accessed: 28 February 2003).

50. Interview of Zahira Kamal (6 August 2002), Jerusalem.

51. Ibid.

52. Interview of Shadia El Serraj (8 August 2002), Gaza City, Palestine.

53. Ibid.

54. Ibid.

55. Ibid.

56. Interview, Hass, supra note 14.

57. Children, the elderly, and the disabled were disproportionately killed by the IDF in its attack on Jenin in 2002. See, for example, Human Rights Watch, "The Bulldozing Death of Jamal Fayid, April 6" in Jenin: IDF M ilitary O perations, online: Human Rights Watch Homepage <http://www.hrw.org/reports/2002/israel3/index.htm\#T opOfPag e>. The report documents the efforts to save a young disabled man from an Israeli army bulldozer:

Despitethe shouting, the bulldozer continued. The women ran out as the house swayed and crumbled around them, crushing the paralyzed Fayid in the rubble. The soldier in the bulldozer cursed at them, calling them bitches. The women ran into another house for safety.

58. The plucking of the beard of an O rthodox priest can constitute torture. See C. Giffard, "The Torture Reporting Handbook" at 3.3, online: The Torture Reporting $\mathrm{H}$ andbook H omepage <http://www.essex.ac.uk/torturehandbook/handbook/part i_3.h tm\#pti_3_3> (date accessed: 28 February 2003).

59. See generally Anderlini, supra note 37 .

60. M ahaAbu-Dayyeh Shamas, "Statement by M ahaAbu-Dayyeh Shamas, Executive Director of W omen's Center for Legal Aid and Counseling, at the Library of Congress, May 9, 2002," online: Bat Shalom of the Jerusalem Link <http://www.batshalom.org/2002/M aha_Congress.htm > (date accessed: $28 \mathrm{Fe}$ bruary 2003). 
61. Interview, Greenblatt, supra note 7. The skepticism is not widely shared, however.

62. Interview, Badran, supra note 7.

63. Greenblatt, Security Council, supra note 10.

64. See Bat Shalom, "They Shoot Pregnant W omen, Don't They?" online: Peace Women H omepage <http://www. peacewomen. org/campaigns/featured/middle\%20east/statsindex.html\#> (date accessed: 28 February 2003). This press release documents the shooting of two pregnant women on the same day. A Palestinian woman was shot by the Israeli army at the entrance to $\mathrm{N}$ ablus whilean I sraeli settler woman was shot by Palestinian snipers.

65. In Israel, for example, four mothersconcerned aboutthe safety of their children who were required to servein thel sraeli army brought an end to the relative silence concerning I srael's invasion and occupation of Lebanon when they demanded to know why, after seventeen years, I srael was still sending soldiers to Lebanon. Their protests gave birth to an organized movement. As Linda Ben Zvi, International Co-ordinator of the Four M others M ovement reported, "These Four M others immediately received tremendouspublic attention. It touched a vital nerve inside Israel. The Four Mothers questioned a central national orthodoxy, namely that the sacrifice of one's children is sometimes necessary in the name of duty." L. Ben Zvi, "Mothers against M ilitary Might: Activism in Israel," (International Conference on Women, Violence Conflict and Peacebuilding: Global Perspectives, London, M ay 5-7, 1999) at 46; the conference proceedings are available online: <http://www.international-alert.org/women/confrep.pdf)> (date accessed: $M$ arch 12, 2003). Ben Zvi notes that this is a variation of the biblical story of Abraham, who was asked by God to sacrifice hisson, Isaac... . O ne of theFour M others said, "[I]f God had asked Sarah to sacrifice Isaac, the answer would have been very different! God must haveknown that, so hedidn't ask her." Ben Zvi, at 46. See also the tragic and compelling story of the Elhanan family in West Jerusalem. Smadar Elhanan was killed by a suicide bomber on September 4, 1997. Her mother does not shrink from laying at least part of the blame on the military and thelsraeli government for the death of her daughter. "They make us die and get killed for nothing." S. Armstrong, "Speaking Peace" Chatelaine M agazine (January 2003) at 107.

66. A Palestinian M other, "I and You." On the second day of the Sukkat Bat Shalom, a Palestinian woman from the Ramallah was visiting her sister in the area. She saw the Sukkah (Bat Shalom PeaceT ent), and shestopped and asked to read a poem to those assembled. She read the poem in Arabic, and a Bat Shalom activist read thetranslation in $\mathrm{H}$ ebrew that thewoman gave her. The poem is a translation by another Bat Shalom activist into English; available online <http://buyorganic.org/ pipermail/peace presence/2002q4/0004 24.html> (dateaccessed: 28 February 2003).

67. N. Elhanan cited in Armstrong, supra note 65 at 114.

68. Interview, Greenblatt, supra note 7 and Interview, Badran, supra, note 7.

69. Interview, Greenblatt, supra note 7.
70. One woman relayed her fear of being caught smuggling into Tel Aviv to deliver a message of peace to Israeli women's groups. She worried that she might be tortured as her son had been tortured by the Israeli military. Interview details withheld.

71. Terry Greenblatt reports receiving threatening e-mails that read likethe following: "I know you arean enemy of I srael and Jews everywhere. As the God of Israel has promised, your bones will be crushed, and your name will be forgotten. Blessed is the God who crushes theenemies of Israel." She goes on to say,

We are scared as we protest in the streets of Tel Aviv and in Palestinian villages under siege. We have stood huddled in small groups of 6 or 7, as well as with the thousands of women and men in 150 cities and towns around the world who stand in solidarity with us. We are harassed and cursed, spat upon and arrested.

The speech also describes how women exchange emergency phone numbers knowing that they put their lives at risk when they participate in practices like monitoring Israeli checkpoints. Spotlight, Greenblatt, infra note 75.

72. Interview, Badran, supra note 7.

73. Interview, Greenblatt, supra note 7.

74. Interview, M iftah, supra note 42.

75. As Terry Greenblatt put it,

The spirit of Oslo was never tested, and therefore it is unacceptable to say that a negotiated settlement is impossible. Oslo didn't fail, we did. I am terrified to know that our leadership was aware of the profound shift in consciousness and public education for peace that were necessary to attempt a negotiated agreement, and was unable to, or chose not to, risk authentically acknowledging the other side as an integral partner for our own success. We never sat down together on the same side of the table and TOGETHER LOOKED at our common and complex joint history, with the commitment and intention of not getting up until-in respect and reciprocity-we could get up together and begin our new history as good neighbors..." "Spotlight on Terry Greenblatt," online: Women Waging Peace Homepage <http://www.womenwagingpeace.net/ content/intheirownvoi ces/spotlight/greenblatt.asp > (date accessed: 28 February 2003).

76. Interview, Greenblatt, supra note 7.

77. Greenblatt, Security Council, supra note 10.

78. On the "Double Binds and Dilemmas of Difference," see $M$. Chamallas, Introduction to Feminist Legal Theory (Aspen: Aspen Law \& Business, 1998) at 17.

79. Shamas, Security Council, supra note 15.

Reem Bahdi is an assistant professor at the University of W indsor, Faculty of Law. Her research and teaching interests includefeminist legal theory, human rights, and international law. 